WENNER-GREN CENTER

INTERNATIONAL SYMPOSIUM SERIES

VOLUME 50

\title{
RESPIRATORY PSYCHOPHYSIOLOGY
}




\title{
RESPIRATORY PSYCHOPHYSIOLOGY
}

Proceedings of an International Symposium held at

The Wenner-Gren Center, Stockholm, September 14-15, 1987

Edited by

\author{
Curt von Euler \\ Nobel Institute for Neurophysiology \\ Karolinska Institute, Stockholm, Sweden \\ and \\ Miriam Katz-Salamon \\ Nobel Institute for Neurophysiology \\ Karolinska Institute, Stockholm, Sweden
}

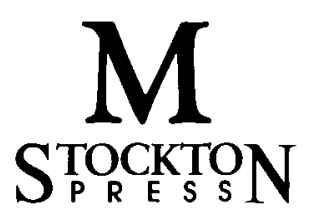


(c) The Wenner-Gren Center 1988

Softcover reprint of the hardcover 1st edition 1988 978-0-333-47491-4

All rights reserved. No reproduction, copy or transmission of this publication may be made without written permission.

No paragraph of this publication may be reproduced, copied or transmitted save with written permission or in accordance with the provisions of the Copyright Act 1956 (as amended), or under the terms of any licence permitting limited copying issued by the Copyright Licensing Agency, $33-4$ Alfred Place, London WC1E 7DP.

Any person who does any unauthorised act in relation to this publication may be liable to criminal prosecution and civil claims for damages.

First published 1988

Published by

THE MACMILLAN PRESS LTD

Houndmills, Basingstoke, Hampshire RG21 2XS

and London

Companies and representatives

throughout the world

British Library Cataloguing in Publication Data

Respiratory psychophysiology:

proceedings of an international symposium held at the

Wenner-Gren Center, Stockholm, September 14-15,

1987.-(Wenner-Gren Center international symposium

series, ISSN 0083 - 7989; 50).

1. Man-Respiratory system-Psychophysiological aspects

I. Euler, Curt von II. Katz-Salamon, Miriam

III. Series

$612^{\prime} .2$

ISBN 978-1-349-10463-5

ISBN 978-1-349-10461-1 (eBook)

DOI 10.1007/978-1-349-10461-1

Published in the United States and Canada by

Stockton Press, 15 East 26th Street, New York, NY 10010

Library of Congress Cataloging-in-Publication Data available

LCCCN 88-24769

ISBN $978-0-935859-53-9$ 


\section{CONTENTS}

Invited Contributors and Participants

Preface and Acknowledgements

Introduction: Forebrain Control of Breathing Behaviour

C. von Euler

Section I

Forebrain Mechanisms in the Control of Breathing

1. The 'Think Test': A Mental Stress Test for Unmasking Hyperventilation in Cardiovascular Disorders P.G.F. Nixon and L.J. Freeman

2. Do the Changes in Respiratory Pattern and Ventilation Seen with Different Behavioural Situations Reflect Metabolic Demands? S.A. Shea, K. Murphy, R. Hamilton, G. Benchetrit and A. Guz

3. Alterations of Inspiratory and Expiratory Control During Silent and Spoken Speech J.M. Patrick and M.J. Hale

4. Respiratory Sensations and the Voluntary Control of Breathing N.S. Cherniack, T. Chonan and M.D. Altose

5. Respiratory Patterning after Prolonged Voluntary Hyperventilation in Man W.N. Gardner, M.S. Meah and C. Bass

6. Psychophysiology of Asthmatic Patients at Night C.M. Shapiro and N.J. Douglas

\section{Section II Respiratory Psychophysics}

7. Respiratory Psychophysics: A Methodological Overview M. Katz-Salamon 
8. Respiratory Sensations During Exercise, Hypercapnia and Voluntary Hyperventilation M.D. Altose, T. Chonan and N.S. Cherniack

9. Panic Disorder and Perception of Added Loads to

Breathing N. Biddle, J. Tiller and M. Pain

10. Comparison of Ventilatory Strategies During Automatic and

Voluntary Breathing J. Gallego and J.-F. Camus

11. Multivariate Support for Three Distinct Approaches to the Assessment of Respiratory Sensation in Patients with Obstructive Lung Disease A. Harver, D.A. Mahler, J.A. Daubenspeck and J.F. McGovern

12. Strategies to Reduce the Effort of Breathing:

Electromyographic and Inspirometry Biofeedback E. Peper

\section{Section III Dyspnea and Hyperventilation}

13. Breathlessness and Respiratory Esophageal Pressure

$O$. Nisell and G. Hedenstierna

14. Diagnostic Criteria for the Hyperventilation Syndrome

H. Folgering

15. Chronic Hyperventilation and Panic Attacks During Sleep

R. Ley

\section{Section IV \\ Bronchopulmonary and Chest Wall Mechanisms in Respiratory Sensations}

16. Upper and Lower Airways' Receptors in Respiratory Load

Perception G. Sant'Ambrogio

17. Proprioceptive Chest Wall Afferents and the Effect on Respiratory Sensation I. Homma, A. Kanamaru and M. Sibuya

18. Adenosine Stimulated Respiration and Pain in Man: Examples of Adenosine Receptor Modulated Afferent Information

B. Jonzon, C. Sylvén and B. Beermann

19. Mechanisms of Respiratory Augmentation by Adenosine: Role of Vagal Pulmonary Afferents M. Runold, N.R. Prabhakar, J. Mitra and N.S. Cherniack

20. What is a 'Normal $\mathrm{CO}_{2}$ '? D. Pilsbury and G. Hibbert 


\section{INVITED CONTRIBUTORS AND PARTICIPANTS}

\author{
Murray D.Altose \\ Pulmonary Division and \\ Department of Medicjne \\ Case vestern Reserve \\ University \\ Cleveland Metropolitan \\ General Hospital \\ 3395 Scranton Road \\ Cleveland, Ohio 44109 \\ USA \\ Nola Bidale \\ Department of Psychiatry \\ The University of Melbourne \\ Clinical Sciences Block \\ C/o Royal Melbourna Hospital \\ Victoria 3050 \\ Australia

\section{I.R. Cameron} \\ United Medical and \\ Dental Schools of Guy's \\ and St.Thomas's Hospitals \\ Lambeth Palace road \\ London, SEl 7FH \\ England \\ Neil. S.Cherniack \\ Department of Medicine \\ University Hospitals \\ 2074 Abington Road. \\ Cleveland, Ohio 44106 \\ USA
}

A.V.Conway

Cardiac Department

Charing Cross Ilospital

Fulhar. Palacs Roaci

London, W6 3RF

England

Curt von Euie:

Nobel Institute for

Neurophysiology

Karolinska Institute

10401 stockholm

Sweden

Leisa Freeman

National Heart Hospital

Westmoreland Street

Londor, WlM 8BA

England

\author{
Hans Th. Folgering \\ Medisch Centrum Dekkervald \\ Universitair Longcentrum \\ Nijmeegsebaan 31 \\ 6564 CA H. Landstichting \\ The Netherlands \\ Jorge Gallego \\ Universite Pierre et \\ Marie Curie \\ Laboratoire de Physiologie \\ Respiratoire \\ 75270 Paris Cedex 06 \\ France
}


W. N. Gardner

King's College School of Medicine and Dentistry of King's College London

Thoracic Medicine

Denmark Hill

London, SE5 8RX

England

Bert Garssen

Medische Psychologie

Academisch Ziekenhuis bij de

Universiteit van Amsterdam

Academisch Medisch Centrum

Meibergdreef 9

$1105 \mathrm{AZ}$ Amsterdam

The Netherlands

E.Griez

Clinical Psychiatry

Rijksuniversiteit Limburg

P.O. Box 616

6200 MD Maastricht

The Netherlands

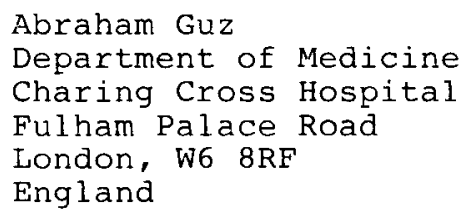

George Hibbert

Department of Psychiatry

University of Oxford

Warneford Hospital

Oxford, OX3 $7 \mathrm{JX}$

England

Ikuo Homma

2nd Department of Physiology

Showa University

School of Medicine

Hatanodai 1-5, Shinagawa-ku

Tokyo 142

Japan
Bror Jonzon

Department of Phsrmacology

Karolinska Institute

10401 Stockholm

Sweden

Miriam Katz-Salamon

Nobel Institute for

Neurophysiology

Karolinska Institute

10401 Stockholm

Sweden

Roland Ley

State University of

New York at Albany

1400 Washington Avenue

Albany, New York 12222

USA

Anne Mier

Department of Medicine

Charing Cross Hospital

Fulham Palace Road

London W6 8RF

Engl and

G.Margo van der Molen

Rijksuniversiteit Limburg

Capaciteitsgroup Medische

Psychologie

Postbus 616

6200 Maastricht

The Netherlands

Ove Nisell

Department of Clinical

Physiology

Huddinge Hospital

14186 Huddinge (Stockholm)

Sweden

P.G.F. Nixon

Cardiac Department

Charing Cross Hospital

Fulham Palace Road

London, W6 8RF

England 


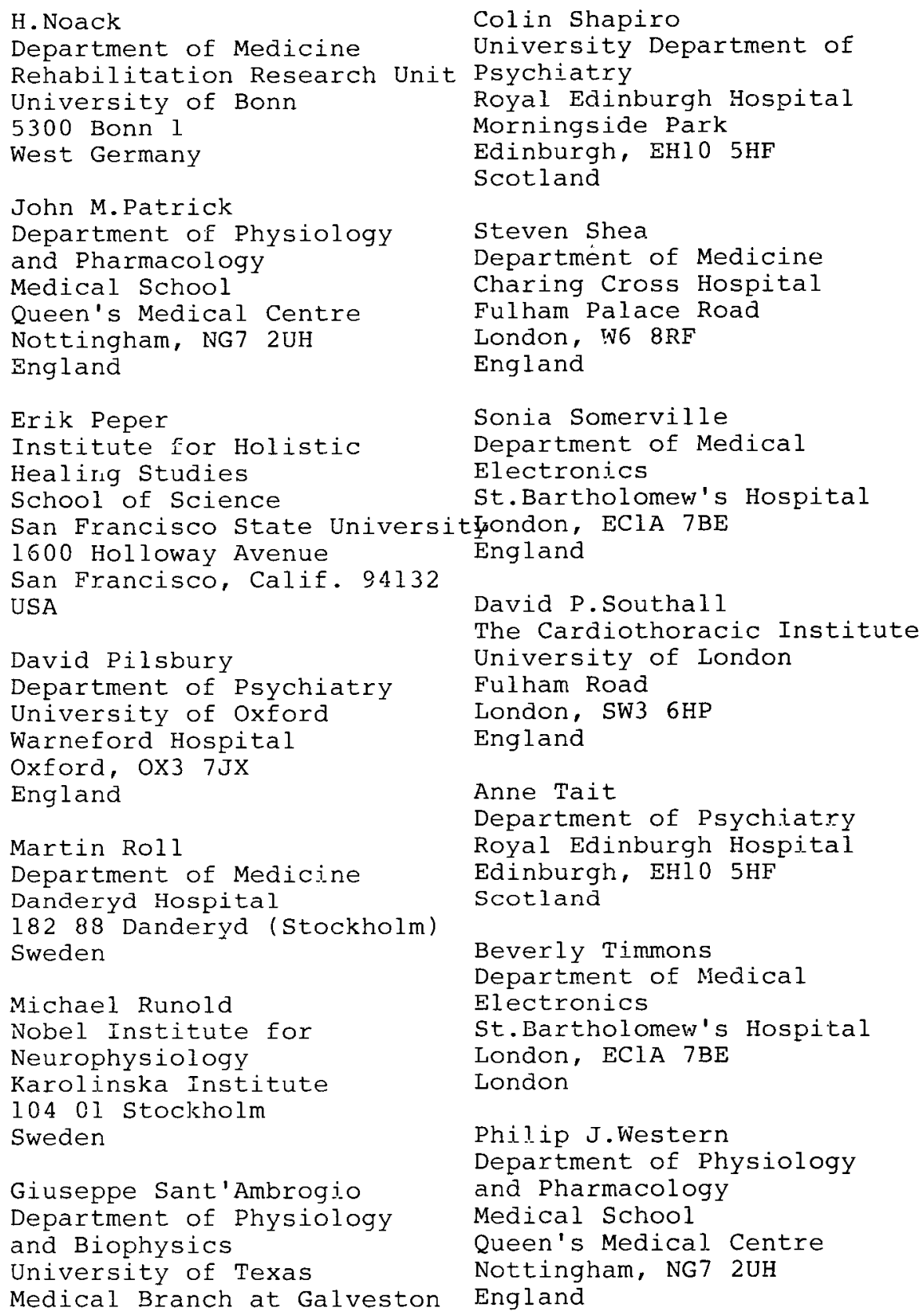


C.J.E.Wientjes

TNO Institute for Perception

P.O. Box 23

3769 ZG Soesterberg

The Netherlands 


\title{
PREFACE AND ACKNOWLEDGEMENTS
}

\begin{abstract}
"If, therefore, someone seriously wishes to investigate the truth of things, he ought not to select one science in particular; for they are all interconnected and interdependent; he should rather consider simply how to increase the natural light of his reason, not with a view to solving this or that scholastic problem, but in order that his intellect should show his will what decision it ought to make in each of life's contingencies. He will soon be surprised to find that he has made far greater progress than those who devote themselves to particular studies and that he has achieved not only everything that the specialists aim at but also goals far beyond any they can hope to reach."'
\end{abstract}

René Descartes (1628)

Regulae ad Directionen Ingenii

(translated in The Philosophical

Writings of Descartes, 1985,

CUP, Cambridge.

Eds J. Cottingham, R. Stoothoff and

D. Murdoch, page 10)

The research area of respiratory functions in health and disease is a multidimensional scientific and clinical field which reaches across the borders of many different scientific disciplines and which is approached from many different angles. During the last decade, growing interest has been focused on sensations related to respiratory functions and dysfunctions and on the roles of the cerebral cortex and other forebrain regions on breathing behaviour, i.e. a research interest which may be referred to as 'respiratory psychophysiology'.

This volume contains material presented at the Seventh International Symposium on Respiratory Psychophysiology held at the Wenner-Gren Center in Stockholm, on September $14-15,1987$. The aim of this symposium was to create a platform for transdisciplinary discussions on current theoretical and clinical problems of physiological, pathophysiological and psychological aspects of respiratory functions. For this reason we brought together researchers from many countries representing the different research areas of respiratory physiology, pulmonary medicine and cardiology, psychology, psychophysics and psychiatry.

A volume based on contributions by many researchers from different scientific fields and backgrounds will inevitably display some semantic ambiguities despite efforts from most authors to use a language also intelligible to colleagues outside their own specific fields.

This symposium was made possible by generous support from the Wenner-Gren Center Foundation for Scientific Research and the Swedish Medical Research Council, both of which are gratefully acknowledged.

Stockholm, 1988

C. von E.

M.K.-S. 